\title{
Abiotic and Biotic Disturbances Affecting Forest Health in Poland over the Past 30 Years: Impacts of Climate and Forest Management ${ }^{\dagger}$
}

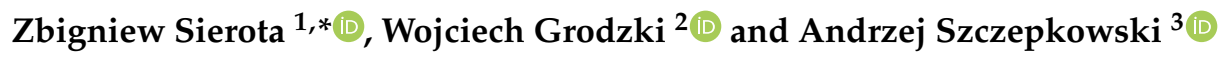 \\ 1 Department of Forestry and Forest Ecology, Warmia and Mazury University in Olsztyn, Pl. Łódzki 2, \\ 10-727 Olsztyn, Poland \\ 2 Department of Mountain Forests, The Forest Research Institute, ul. A. Fredry 39, 30-605 Kraków, Poland; \\ w.grodzki@ibles.waw.pl \\ 3 Department of Forest Protection and Ecology, Division of Mycology and Forest Phytopathology, \\ Warsaw University of Life Sciences-SGGW, ul. Nowoursynowska 159, 02-776 Warsaw, Poland; \\ andrzej_szczepkowski@sggw.pl \\ * Correspondence: zbigniew.sierota@uwm.edu.pl; Tel.: +48-89-523-49-47 \\ + To mark the centenary of Poland's Independence.
}

Received: 29 December 2018; Accepted: 18 January 2019; Published: 21 January 2019

\begin{abstract}
The current nature of forest management in Poland reflects its history and more than 100 years of economic activity affecting forests since independence in 1918. Before that time, different forest management models were used, related to the nature of the Prussian economy in the north of the country, the Russian economy in the central-eastern part, and the Austrian economy in south-eastern Poland. The consequence of these management models, as well as the differing climate zones in which they were used, resulted in varied forest health. Since the end of World War II, forest coverage within Poland's new borders has increased from $20.8 \%$ to currently $29.6 \%$, mainly as a result of afforestation of wastelands and former agricultural lands. This paper describes changes in the health of forests and their biological diversity in Poland in the context of weather extremes, species composition, forest management, the forest industry, and damage from insects and pathogenic fungi over the last 30 years.
\end{abstract}

Keywords: forestry models; climate change; forest management; abiotic and biotic disturbances; forest health

\section{Introduction}

In order to assess and understand the reasons for the present state of Poland's forests, it is important to be aware of the historical conditions in which forest management in Poland was shaped. Historical changes in the management of forests, their location, and vegetation variability were important predisposing factors leading to declining forest health in Poland and other parts of Central Europe in the 1970s. [1]. Since 1795, and during the nineteenth century the area of the Federal Kingdom of Poland and the Grand Duchy of Lithuania were, at different times, divided between three neighboring countries - Germany in the west (with Prussia in the north-east), Austria-Hungary in the south-east, and Russia in the central and eastern areas [2]. This split also impacted forest policy, forest management, and stand protection up until Polish independence in 1918.

\section{Models of Forest Management in the Nineteenth Century}

Silviculture and forest planning processes were first developed, and most strongly implemented, in Germany and Prussia, prior to the eighteenth century. Bans on removing manorial forests were 
introduced, and the concept of forest conservation was promoted in 1713 by the publication of $H$. von Carlowitz's "Silvicultura oeconomica", which promoted the principles of sustainable forest management [3]. In the Austro-Hungarian Empire, after F. Hohenzollern's Act for Silesian forests (1777), local governments often regulated forest management_for example in the Beskidy mountain region (southern Poland, western Carpathians) at the end of the nineteenth century, there were already forest companies who worked in district forests owned by local communities and the Polish aristocracy [4].

The forest industry was historically a source of employment and consumer goods, but at the same time it harmed both people and the environment. Industrial factors caused reductions in forest area, which resulted in a significant loss of natural fir, oak, beech, and sycamore forests. Forest loss was most severe in the Sudetes and in the western Carpathians (Southern Poland) [5-7]. The depletion of natural forests, both in mountainous regions and in northern and north-eastern areas (Prussia), was a consequence of the rapid development of the industrial economy in the second half of the nineteenth century. Similar forest loss occurred in all regions of Europe, often much earlier than in Poland [3,8]. The theories developed at the beginning of the nineteenth century by German forestry (e.g., W. Pfeil, M. Faustmann), were founded on the principle of obtaining maximum economic income from the forest over its rotation, which is not necessarily the same as harvesting the largest volume of wood [3,9]. As a result, there was considerable tolerance of the market for forest management by land owners, which included clearcutting and the reduction of diverse forest species. In place of the original multi-species, multi-storey forests with a complex physical and ecological structure, forests were managed as "regulated" monocultures. In Prussia and Hessia, from 1819, forests were often harvested on a 100-year cycle, "regulated" using a harvesting cycle where a fixed percentage of the forest was harvested. If the forest was renewed at all, regeneration was mainly with spruce, a fast-growing tree in climatic conditions. Planted trees usually originated from seeds of non-local origins, and were rarely from local populations [10-12]. It was then believed that properly guided harvesting would provide forest owners with a steady maximum income from the forest, and at the same time harmonize the supply of wood to meet industry demand. However, forest practices prior to the twentieth century did not take into account the possible impact of such processes.

As the demand for timber grew rapidly in the nineteenth century, the availability of easily accessible forests for logging dwindled. Planned forest management was increasing, forest offices were being established, and forestry education was developing. This was especially the case in Germany, Austria-Hungary, and Prussia [1]. In place of simply harvesting wood without regard to long-term sustainability of wood supply, silvicultural models of wood production were introduced that drastically changed how forests were harvested, taking into account the age class composition of forests and the need to conserve tree species. It seems that, even today, this modern model for organizing the spatial and temporal structure of managed stands continues to have a positive effect on the development of forest resources and has enabled the management of multiple societal objectives for forests [13]. Only a few writers, such as J.Ch. Hundeshagen and O. Hagen, sensing the looming crisis facing forests, sought to protect them from overharvesting [14]. They had in mind both the impact of forests on moderating climate and reducing soil erosion, as well as the need to preserve forests for future generations, which was expressed in 1804 by L.G. Hartig, one of the co-creators of modern forestry. His vision became the famous slogan of the Second Ministerial Conference on Forest Protection in Europe-Helsinki 1993: "for future generation" [15].

Meanwhile, fire protection practices and the first forest fire insurance were created (1860 in southern Poland, 1862 in the west), which took on special significance after large forest fires occurred in 1863 (3.5 thousand hectares burned in the west) [16]. The planned forest economy began to be implemented, mainly thanks to the work of Schwappach (1908) and Wiedemann $(1925,1948)$, resulting in table-based stand growth models [17].

A slightly different approach to forest management and forest protection prevailed in areas under Russian rule after 1795 . First of all, national and private property were nationalized which resulted in 
forests no longer being associated with the privileged classes in Poland. In 1892, forest management resulted from the new provisions of the Empire, and the existing provisions of the Kingdom of Poland (beginning in 1898), with new laws for forest protection being introduced along with punishment for their violation [16]. Nevertheless, illegal logging for timber exports and resulting deforestation by landowners still took place, worsening the health of forests [1]. Only government and municipal forests were managed by state forest services, and, thanks to that, they received better management [18].

\section{Changes in Forest Cover and Forest Management Strategies in Poland}

Wars repeatedly took place on the territory of Poland-from the Napoleonic Wars (1815), to World War I (1914 to 1918), and World War II (1939 to 1945), which dramatically reduced the area and health of forests. These conflicts caused a significant decrease in forest area, which occurred over the 120 years of Polish occupation, until 1918. In areas under Russian control and in mountainous regions (Sudetes, Carpathians) $[6,19,20]$, forest cover decreased from $30.9 \%$ (3.8 million ha) in 1815, to 19.2\% (2.3 million ha) in 1913 [18]. Over the country as a whole, at the end of the eighteenth century forest cover was about $40 \%$, which decreased to $23 \%$ in 1921 and 22.2\% in 1937 [21]. The period from 1939, especially as a result of World War II, not only saw massive deforestation and illegal logging in the areas occupied by Nazi-Germany and Soviet Russia, but also local forest losses occurred due to droughts, fires, and insect damage. For example, the extended bark beetle (Scolytinae) outbreak that started just at the end of the war, affected spruce forests in the Sudetes and Western Carpathians [20,22]. Bark beetles, together with outbreaks of Nun moth Lymantria monacha (Linnaeus, 1758), affected forests in the region of Mazury in north-eastern Poland [23]. These events caused a decline in the forest cover of Poland within its new borders to $20.8 \%$ in 1946 [24].

Forestry changed considerably in the post-war period as it came to be recognized for its contributions to the national economy and was increasingly being seen as an element of the natural environment. The main task of the newly created State Forests (established in 1924), was to rebuild the national forest estate. After World War II and the establishment of the communist government, all forests with an area exceeding 25 hectares were nationalized [25]. Furthermore, afforestation was undertaken on large areas of vacant land, including wasteland, abandoned unproductive agricultural land, dunes, and pastures [26]. Between 1946 and 1970 over 2 million hectares of forest plantations were established, mainly of pine, spruce, and birch, increasing forest cover to $28 \%$.

The above-mentioned afforestation was treated as forecrop, which should re-shape or restore forest soil in a given area. Afforestation on such a large scale was an innovative venture in Europe, with previously unknown scientific premises for tree breeding. However, Poland did not avoid actions that we would today call 'mistakes' - even-aged monocultures covering large areas were created. Many trees were affected by root deformation from poor planting practices, and there was insufficient attention paid to controlling cockchafer (Melolontha spp.) larvae [27]. Furthermore, the importance of mycorrhizae for tree health was unknown [28,29]. The result of these practices was that, after 15 to 20 years, many of these plantations were under physiological stress, which contributed to a massive outbreak of root rot (Heterobasidion spp.) [26] At the same time, there were increasing outbreaks of defoliating and wood boring insects [30,31], especially in stands growing on rich sites [32]. Altogether, these factors caused significant economic losses and ecosystem changes [5,33].

The years from 1950 to 1970 mark the period of the Poland's socialist economy, in which forest supplied wood was particularly vital to forest-related industry. Forest produced wood enabled the manufacture of stamping mills for mines, railway sleepers, power poles, as well as for the furniture and sawmill industries. Forest stands, however, managed in accordance with the then binding regulations and principles of tree breeding and forest management, were subject to forced summer harvesting, resulting in a thinning of every four to six rows in plantations, and widespread spraying to control insect pests with insecticides that were harmful to the environment [34,35]. Dead wood, although now recognized for its ecological importance, was then often removed as it was considered as wastage and economically negligent. 
New concepts, such as 'biodiversity', 'environmental protection', and 'sustainable development' appeared in Poland towards the end of the 1980s, after the change of political system. This marked the transition from forestry that was mainly focused on the production of raw materials to a semi-ecological forestry approach [36-40]. New concepts in Polish forestry, such as "forestry in accordance with nature", "semi-natural forest breeding", and "protection of natural resources in forests" were in line with a growing recognition of such principles elsewhere following the World Commission on Environment and Development (WCED) Report (1987), the Earth Summit (Agenda 21, 1992), and the Helsinki Resolution (1993) [15]. As a result, in many regions of the country, a large program of forest conversion was undertaken to replace conifer monocultures with mixed species stands, using species mixtures amenable to habitat requirements, care for biodiversity, and limitation of chemical methods for biological and ecological activities [41]. As a result, by 2016, forest area had increased to 9.2 million ha (29.5\% of the country's area) and, according to the goals of the National Program for Increasing Afforestation, by 2050 forest cover should increase to $33 \%$ of the country [42].

\section{Abiotic and Biotic Disturbances in Forests}

In addition to harvesting by the forest industry, including logging by neighboring countries, Polish forests have been subjected to droughts, hurricanes, fires, fungal diseases, and dieback caused by atmospheric pollution $[5,10]$. Brazdil [43] notes that from the end of nineteenth century in the north of the present day Czech Republic, it was not only human activity that changed species diversity of natural mountain forests, and introduced more economically preferred species, mainly Norway spruce, but also sulfur dioxide $\left(\mathrm{SO}_{2}\right)$ pollution from industrial regions from the south-west. In former East Germany (GDR), for many years, 0.8 million ha of lowland stands were degraded due to industrial emissions, mainly of $\mathrm{SO}_{2}$ [44]. A similar situation occurred for many years in the adjacent forests of Poland [45,46]. Similarly, the so-called "Black Triangle" (the Izerskie and Ore Mountains in the western Sudetes) was exposed to very high levels of industrial pollution $[10,47,48]$, that indirectly-by the weakening of trees-is one of the most important factors stimulating bark beetle outbreaks [49]. The dieback of forest plantations increased through the 1970s and 1980s in Central and Eastern Europe, and in many papers it was described as 'Waldsterben', or 'forest decline' [49-52].

The present characteristics of forests differ in various parts of Poland that were once under German (north-western), Russian (north-eastern), and Austro-Hungarian (south-eastern) control, in ways that can be traced to each area's former economy. Specific forest health problems include forest insect outbreaks that are related to the dominant tree species in each region.

In the north-western region, Scots pine dominated stands have been, and still are, affected mainly by defoliating insects, such as the Nun moth, L. monacha. Outbreaks of Nun moth occurred for several decades. In the period 1946 to 75, insecticide treatments during six L. monacha outbreaks were applied on a total area of 7.3 million ha of Polish land [53]. The largest L. monacha outbreak took place between 1978 and 1984 [54,55]—in 1982 alone over 2.3 million ha of forest were sprayed with pyrethroids [53]. During the 1992 to 1994 outbreak, insecticide was applied to about 0.7 million ha [35] (Figure 1). After the largest L. monacha infestation, cyclical damage to forests also occurred due to minor outbreaks of often co-occurring sawflies (Diprionidae) as well as pine defoliators, such as Panolis flammea (Denis and Schiffermüller, 1775), Bupalus piniaria (Linnaeus, 1758), Dendrolimus pini (Linnaeus, 1758) [35] (Figure 1). However, in recent years the use of insecticides has been strongly reduced due to European legal regulations [35]. Weakened trees were prone to subsequent attacks by bark and wood-boring insects, such as Tomicus minor (Hartig, 1834), Ips acuminatus (Gyllenhal, 1827), and Phaenops cyanea (Fabricius, 1775) [30]. 


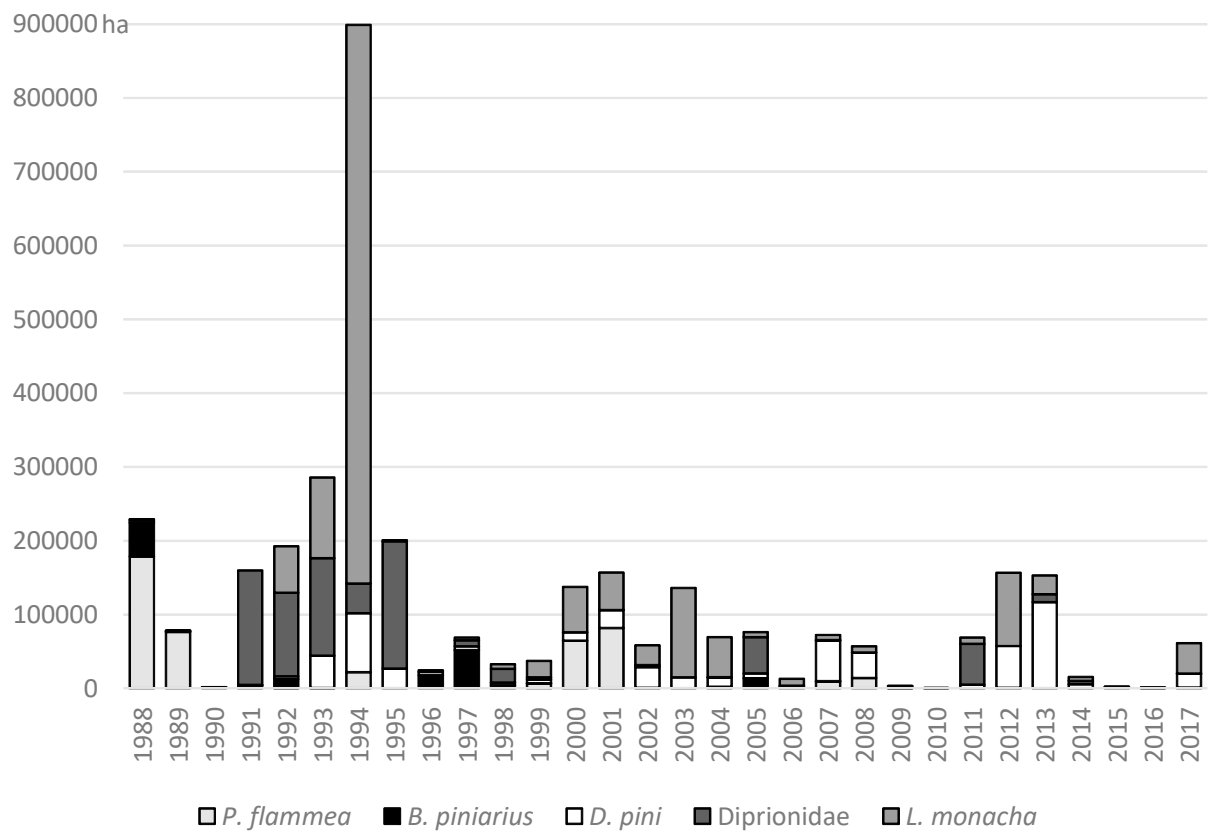

Figure 1. Area of aerial chemical insecticide treatments against pine defoliators in Poland between 1988 and 2017 ([35], modified).

Forests in north-eastern Poland are more diversified, but still contain a high proportion of Scots pine, Norway spruce, and oak. Extended outbreaks of bark beetles, mainly Ips typographus (Linnaeus, 1758), occur in spruce-dominated stands [56]. Cyclical I. typographus outbreaks occur in the area of the Białowieża Forest, due to the large areas of Norway spruce that occur there [57]. These outbreaks cause deep controversies concerning the active control of insect populations, especially during the most recent outbreak that started in 2012 [58]. Another problem is the occurrence of wood boring insects in oak stands, such as Agrilus spp.- especially A. biguttatus (Fabricius, 1776) [59], that cause oak decline throughout Europe [60].

The third region, formerly under the control of Austria-Hungary, is located in the south-east, mostly in mountainous terrain, where specific site conditions shape the natural features of forests. As mentioned earlier, due to former (more than 150 years ago) approaches to forest management, stands, especially in the western part of the region, are dominated by Norway spruce that was artificially planted from non-local seed origins. Such species composition has strong effects on forest health problems [8]. The main biotic agents responsible for forest decline in this region are those affecting Norway spruce: Armillaria ostoyae (Romagn.) Herink [61] and bark beetles, mainly I. typographus [62-64].

In 2003 to 2010 an extended bark beetle outbreak resulted in partial or total deforestation of mountain slopes in the Beskidy Mountains $[8,63]$, where the yearly number of processed logs from trees infested by bark beetles reached more than 1 million $\mathrm{m}^{3}$ in 2007 to 2008 (Figure 2). In recent years, a new bark beetle outbreak has taken place, started by water stress in Norway spruce after the drought of 2015, affecting stands in the western Carpathian and Sudetes mountains (Figure 2). The ongoing drought conditions, combined with already high bark beetle populations, make the risk of a further outbreak extremely high [63]. 


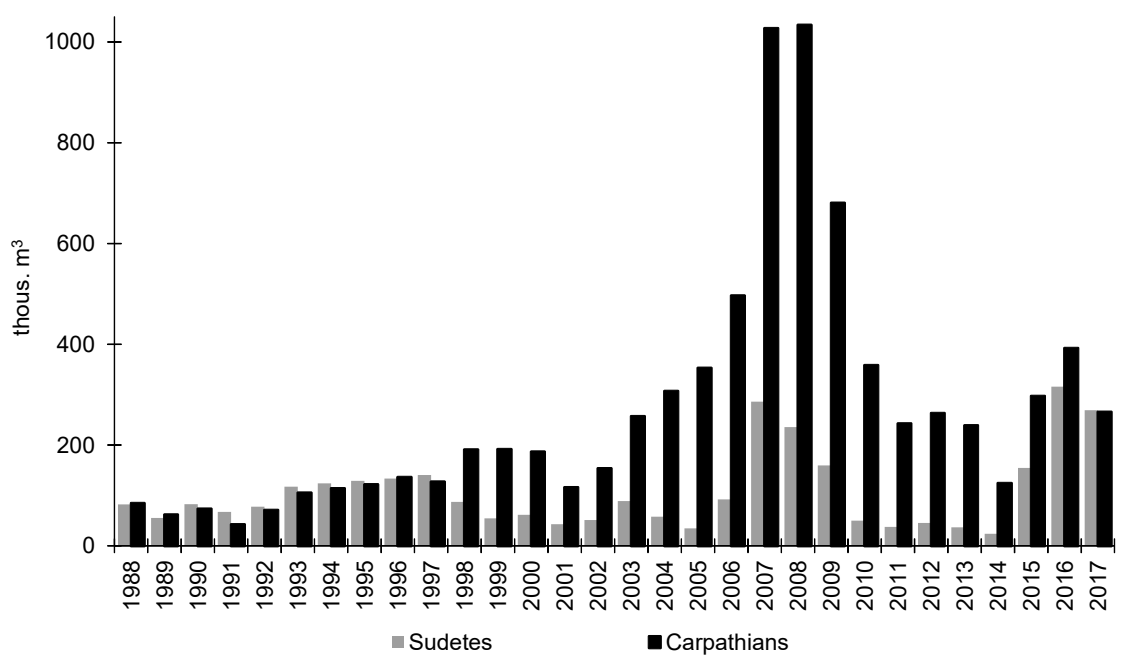

Figure 2. Volume of harvested spruce logs affected by bark beetles from trees in the Carpathian and Sudetes mountains between 1988 and 2017.

Outbreaks of damaging insects often co-occurred with increased incidences of fungal diseases (Figure 3). In the early 1950s, there were high levels of damage in spruce stands caused by Armillaria spp. (65 thousand hectares affected). In the following decades, Scots pine, the main forest tree species in Poland, was affected by foliar diseases. For example, in 1996, 950,000 hectares of Scots pine stands were affected by Lophodermium pinastri (Schrad.) Chevall., L. seditiosum Minter, Staley and Millar, Gremmeniella abietina (Lagerb.) M. Morelet (=Ascocalyx abietina (Lagerb.) Schläpf.-Bernh.), Cenangium ferruginosum Fr., and Dothichiza pithyophila (Corda) Petr. [5]. Stands in which these diseases occurred largely occupied former agricultural land, where the root rot Heterobasidion annosum sensu lato was endemic. The forest area affected by this root rot grew annually, reaching 5\% (200 thousand hectares) of afforested land in 1997 in Poland [26]. In the past 30 years, local forest decline has been repeatedly recorded-silver fir decline in the 1970s (caused mainly by air pollution) [46], oak decline [65], ash dieback caused by Hymenoscyphus fraxineus (T. Kowalski) Baral, Queloz and Hosoya (Chalara fraxinea T. Kowalski) [66,67], and recently, dieback of Norway spruce stands caused by drought, root pathogens, and bark beetles [63]. Presently, dieback is considered to be caused by a combination of several factors $[68,69]$. 


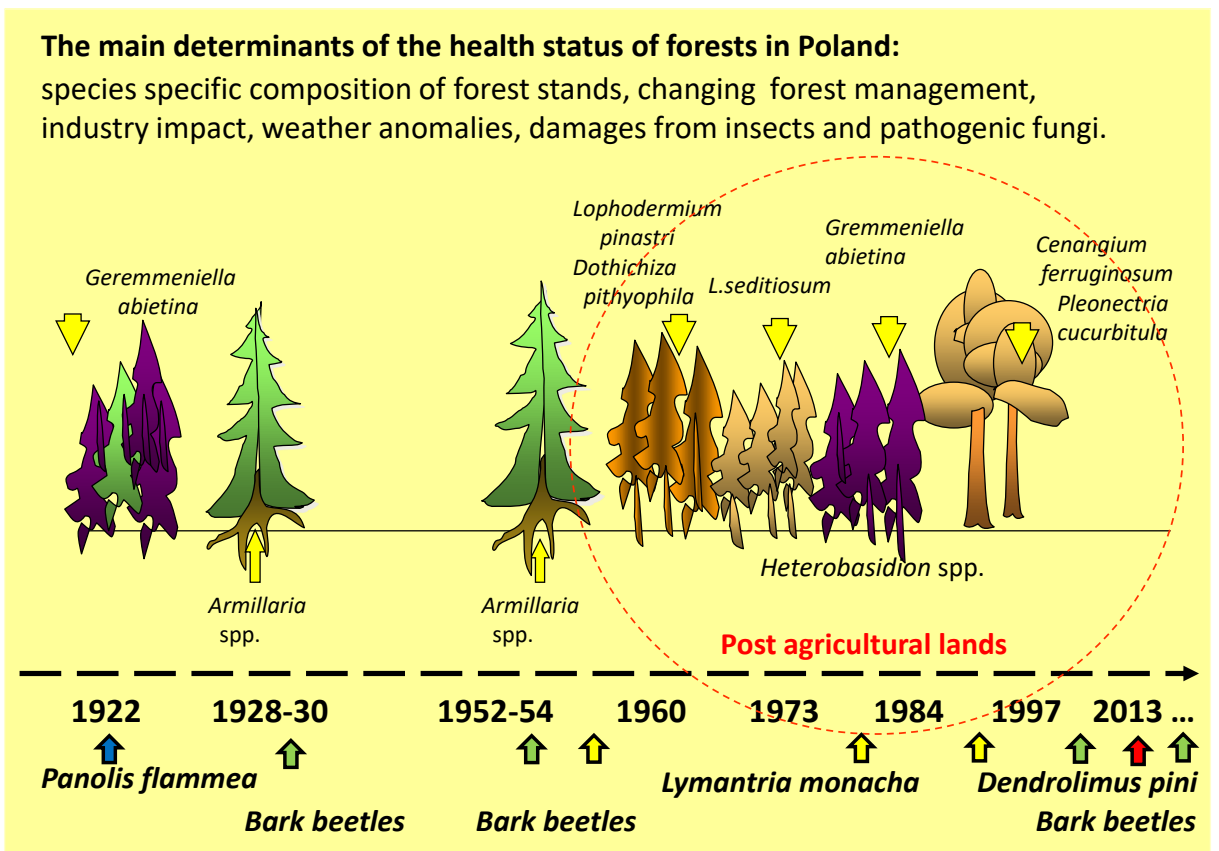

Figure 3. Main fungal diseases and insect pests causing forest mortality since 1922 in Poland [70].

\section{Impact of Climatic and Economic Change on Forest Ecosystems in the past and Now}

Natural disasters affecting forests cause large quantities of dead organic matter to accumulate, thereby promoting populations of wood boring insects. After World War I (1923 and 1924), outbreaks of defoliating insects (e.g., Panolis flammea) occurred on several hundred thousand hectares of State forests, located mainly to the west of the Vistula River [1]. After World War II in forests heavily damaged by war and occupying forces, the range and intensity of insect damage increased significantly, causing severe damage to Scots pine forests in northern and western Poland.

The large-scale regeneration of forests was not only a serious logistical problem, but also a tree seed supply and tree breeding problem, because the appropriate genetic source of specific seeds was needed for the stands that had to be replanted [41,71]. In lowland areas, it was easier to reconstruct natural species composition, whereas in mountainous regions, due to the protective functions of forests, such reconstruction was a complicated process [72]. Forest decline in the Izerskie Mountains in the 1980s resulted in the planting of diverse forest species, which today form young multi-species stands [73] (Figure 4), although specific problems caused by Ips cembrae (Heer, 1836) affected young larch trees [74]. An unexpected problem was the decline of older stands in the southern part of the Beskidy Mountains, which were considered more resistant to pollution and biotic damage [12,75,76], although their advanced age was expected to make them more vulnerable to bark beetle attacks [64]. Unfortunately, forest decline has affected even the famous spruces of Istebna, known for their high quality (e.g., "Anderson's spruce" a single tree with a volume of $11 \mathrm{~m}^{3}$ ), [12,77], many of which have now died, reducing the amount of spruce in this region by $30 \%$. This is attributed to protecting spruces to an over-mature age, making them more susceptible to root rot diseases, repeated insect outbreaks, as well as to damage by strong winds and breakage by heavy snowfall [64]. 

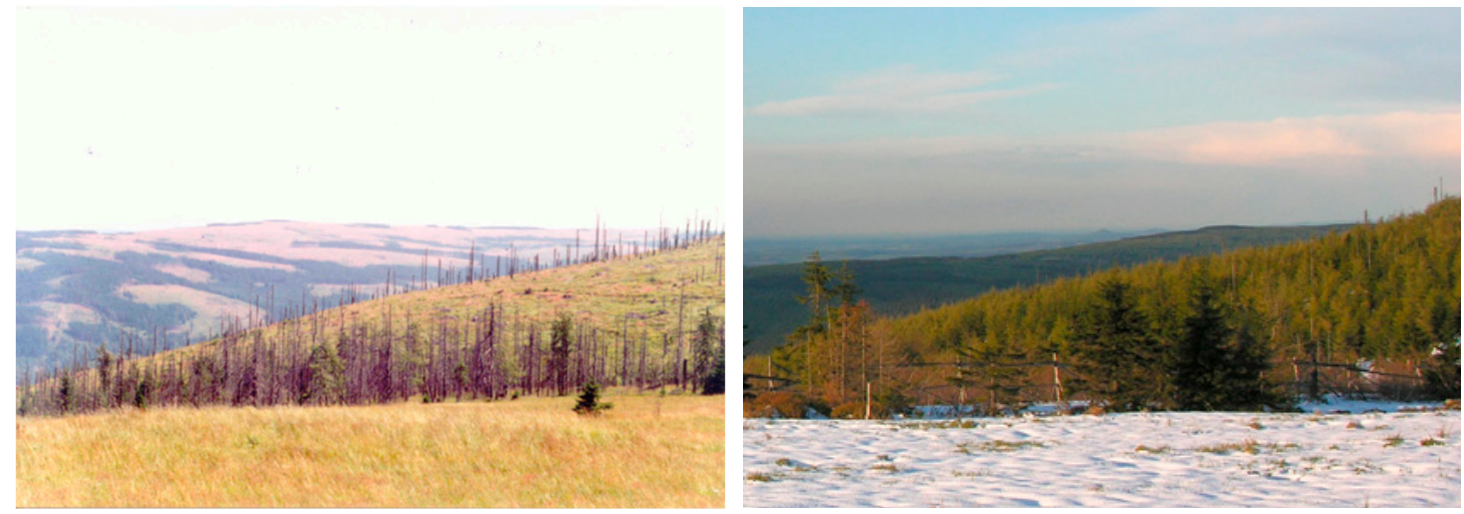

Figure 4. Forest stands in the Izerskie Mountains: Decline (1992) and recovery (2005). Photo by W. Grodzki.

Increasingly warmer winters, a lack of winter snowfall, and reduced rainfall during the growing season, have resulted in mortality of many different tree species. Of note, is the dieback of spruce in Poland, observed for about the past 15 years, due to long-term drought and reduced soil moisture levels. Mortality of ash has occurred for many reasons, including the fungus Hymenoscyphus fraxineus, responsible for crown dieback, while other deciduous species have been affected by several root pathogens (e.g., Phytophthora spp., Armillaria spp., Heterobasidion spp.) [5].

The weather in different seasons and years was different across the country, due to climatic conditions, as well as to influence of large lakes and forest areas in the north-east, of lowlands with limited forest area in central Poland, and of high mountains in the south. In 1992, extreme drought occurred in central and southern Poland, whereas in the north the growing season was wet, whereas the growing seasons in 2014 and 2015 were very dry throughout the country (Figure 5).

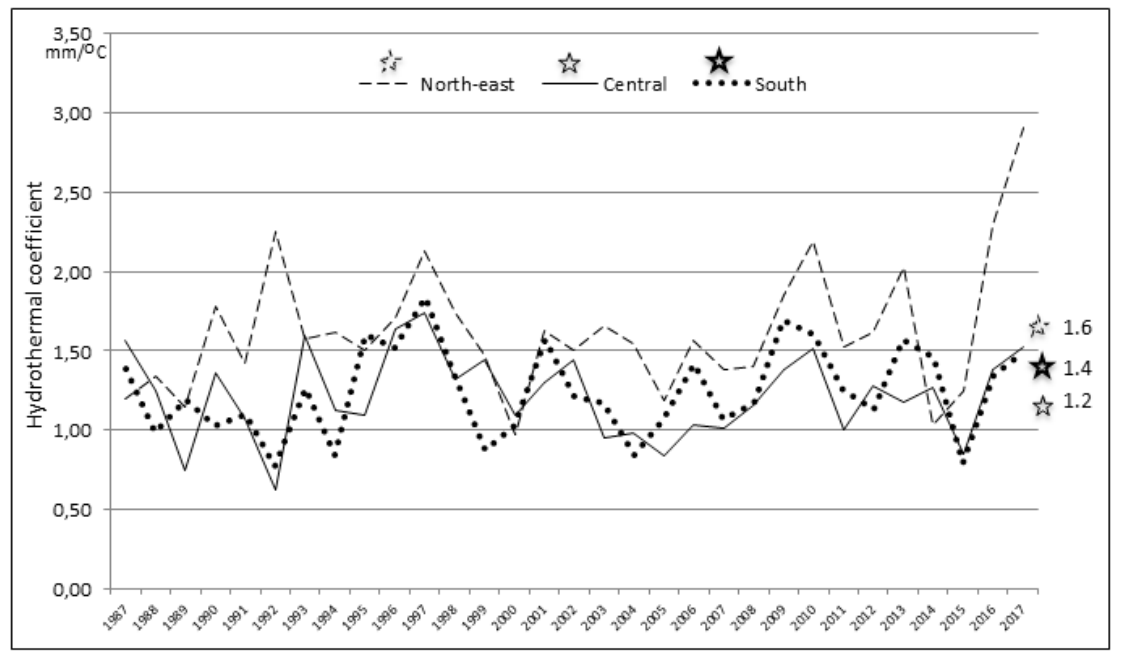

Figure 5. Values of Sielianinov's hydrothermal coefficient, $K(K=P \times 10 / \Sigma \mathrm{t})$ for three regions of Poland during the last 30 years (lines) and multi-year average (stars), where $P$ is the sum of precipitation and $\Sigma t$ is the sum of average temperatures during the period. Ranges of $K$ values for the period are interpreted as extremely dry (0 to 0.4$)$, very dry (0.41 to 0.70$)$, quite dry (0.71 to 1.0$)$, dry (1.1 to 1.3$)$, optimal (1.31 to 1.6$)$, moist (1.61 to 2.0$)$, wet (2.1 to 2.5$)$, and very wet (>2.5).

A few years were unique in the history of Polish forests-three large-scale fires in August 1992 (burning 20 thousand hectares in total), widespread flooding of the Nysa and Odra rivers in the west in July 1997 (affecting an area 665.8 thousand ha), high winds in the Pisz Old Forest in the north-east in July 2002 (12 thousand ha), and a hurricane in northern Poland in August 2017 (7.5 million m ${ }^{3}$ of 
blowdown trees). Only the growing seasons of 1997, 2001 to 2002, and 2010 were characterized by favorable weather conditions for forests, without any large scale insect or fungus infestation, although subsequent years were affected by the major disturbances mentioned above [5].

\section{What Might the Future Hold for Polish Forests?}

Projections for climate change in the twenty-first century, both for Europe as a whole and Poland in particular, predict increases in air temperature, and thus soil temperature, in all seasons [78-80]. In addition, changes in precipitation and increasing concentrations of $\mathrm{CO}_{2}$ in the atmosphere as a result of greenhouse gas emissions and other pollutants may alter tree species composition. The predicted warming along with nitrogen accumulation from pollution in habitats may mean gradual northward and higher elevational shifting of tree ranges, which will promote deciduous tree species at the expense of the area currently occupied by coniferous species [81-84]. In this part of Europe, the participation and importance of native deciduous trees - beech, birch, linden, and oaks - will probably increase. Non-native species may also appear, including invasive species adapted to warmer temperatures, such as white robinia (Robinia pseudoacacia L.), wild black cherry (Prunus serotina Ehr.), and red oak (Quercus rubra L.) [85]. One should expect a reduction of coniferous species, especially spruce, maybe fir, and, to a lesser extent, pine $[46,86]$.

In the coming years, one of the most important effects of climate change will be its impact on the resilience and health of existing and new forest stands. The increasing frequency and intensity of extreme weather, such as droughts, long periods of high temperature, strong winds, heavy rains, and floods, increase the susceptibility of trees to physical damage, disease, and pests. In addition, climate change can affect the developmental cycles of pathogenic organisms, which in turn may increase threats to trees $[70,87,88]$. Some species, e.g., endophytes that are of marginal significance to date, such as Ips acuminatus, may gain in importance and become serious threats as pathogens/pests [35,89]. It should be remembered that alien and invasive species may appear more frequently [90], as demonstrated by a number of recent examples, such as Obolodiplosis robiniae (Haldeman, 1847), Coleotechnites piceaella (Kearfott, 1903), Phylonorycter issikii (Kumata, 1963) [91].

Changing environmental conditions (e.g., increased soil and air temperature, milder and snowless winters), but also free trade and the long-range shipping of goods favor the emergence of an increasing number of non-native species of fungi in Poland from warmer regions of the world. An example of pathogens of great threat to forest trees in Poland, which until recently were only present in southern Europe, are representatives of the genus Phytophthora and Sphaeropsis sapinea (Fr.) Dyko and B. Sutton-both may cause dieback of trees [92-94]. One can also expect the spread of fungi affecting trees, responsible for root and stem rot of living trees in Poland, e.g., Ganoderma resinaceum Boud. or Perenniporia fraxinea (Bull.) Ryvarden [95-98]. An example of the spread (from south to north) of exotic fungal species in Polish forests are saprotrophic ground fungi, members of the stinkhorn (Phallaceae) family: Pink stinkhorn Mutinus ravenelii (Berk. and M.A. Curtis) E. Fisch and octopus stinkhorn Clathrus archerii (Berk.) Dring [99]. To date, there is no evidence of the negative impact of alien stinkhorns on native species of mycobiota or on other elements of forest ecosystems. However, it cannot be ruled out that in the future they may compete with indigenous saprothropic, or even mycorrhizal fungi, exerting some negative (direct or indirect) impact on plants, including trees. Intentional or natural regeneration of non-native woody plants made possible by changing climatic conditions may result in the appearance of non-native species of mycorrhizal fungi, which could affect native mycobiota and displace native species of ectomycorrhizal mushrooms [100].

Under warming conditions with more intense droughts, many insect species can be expected to increase. Thermophilic species with a southerly distribution will increase. Significant damage may be caused by species considered thus far as pests of secondary importance, such as I. acuminatus [87,89] and I. cembrae [74]. An increase in the frequency of severe drought is expected [101], which, when combined with the emergence of insect species that have been found in Poland (e.g., Anoplophora 
glabripennis (Motschulsky, 1853) [102], Xylosandrus germanus (Blandford, 1894) [103], Gnathotrichus materiarius (Fitch, 1858) [104], can lead to widespread tree mortality.

Potential increases in deciduous species (e.g., beech, oaks) may fail to materialize if trees are affected by disease, due to the occurrence of phytophthorosis of these species, as well as fungi of the genus Neonectria - causing bark damping and beetroot cracks, the activity of Armillaria spp., and wood boring beetles of the Agrilus genus, as recently observed in oak stands [60,65,105-110]. On moist sites that are exposed to drought, hydric tree species (ash, alder, elm) will be exposed to adverse abiotic and biotic factors that may lead to a drastic decline in their condition or even large-scale dieback, for example due to Phytophthora spp. [93], Ophiostoma novo-ulmi Brasier, or dying ash, for which Hymenoscyphus fraxineus (Chalara fraxinea) is responsible [66,67].

Over the next few decades, coniferous species (Pinus sylvestris, Picea abies) will be strongly exposed to insect pests and pathogenic factors. In particular, pine monocultures established in the past on former farmland soils, as well as spruce monocultures in lower montane zones, are likely to see increased infection by root pathogens (Heterobasidion spp., Armillaria spp.), which will require replanting to alter species composition [41,111]. In drought conditions, the negative impact of fungi that produce rhizomorphs (including Armillaria) will increase. Since rhizomorphs are capable of growing through the soil for long distances (many meters), they are better able to survive drought conditions by transporting water, carbohydrates, and minerals [105,112-114]. In addition to changing tree species planted in such areas, activities should be undertaken to eliminate food sources of root pathogens (e.g., removing stumps and major roots of dead trees in affected areas). Control of root rot fungi is also recommended using a proven biological method of introducing native strains of Phlebiopsis gigantea (Fr.) Jülich, which on contact competes with the spread of hyphae of some root rot fungi $[26,41,115-117]$.

Pine in fertile habitats produces root system tiles, which in the case of water shortage and weakness by other abiotic factors, leads to an increase in susceptibility to attacks by bark and wood boring insects, e.g., Phaenops cyanea, Ips acuminatus [118]. Weakened pine trees of practically any age, due to disturbances in water management can be exposed to attacks by pathogens causing dieback (Gremmeniella abietina, Cenangium ferruginosum, Sphaeropsis sapinea, Pleonectria cucurbitula (Tode) Hirooka, Rossman and P. Chaverri) $[35,70,119]$.

Spruce is sensitive to high temperatures and drought, both of which have occurred in the last two decades. As a result, there has been a high rate of spruce mortality, especially in the south of Poland. Bark beetles such as Ips typographus may be attracted to spruce trees whose roots are infected by Armillaria ostoyae, as the fungus can result in the foliage releasing certain chemical compounds $[61,63,64,105]$. In the coming years, biotic and abiotic factors affecting spruce forest health are likely to persist, and even greater rates of tree decline can be expected.

Climate change may increase the frequency, intensity, and area affected by natural disturbances (fires, wind storms, and snowstorms) in forest ecosystems. The large number of dead trees will be conducive to the development of numerous species of saprotrophic fungi and insects associated with heavily damaged forests.

Already today, forest management faces the need to improve stress prevention and management for improved health in post-conflict forest areas. It is advisable to choose strategies based on scientific principles. An important task in the future will be monitoring and cross-border control of harmful pathogenic insects and fungi. Or indeed: 'Omnia subiecta sunt naturae' ? (Everything is subject to nature)-Democritus (460 to 375 years b. Ch.).

\section{Conclusions}

Forests in Poland, mostly growing in a climatic transition zone, are strongly diversified but vulnerable to disease and insect outbreaks. Although specific traits resulting from different management in the past still affect forest characteristics (especially species composition and forest structure) and related threats caused by abiotic and biotic factors, the overall health and vitality of 
Polish forests is good. Political and economic transformation have reduced the negative impact of the forest industry on forest health, and, due to new forest policies, the forest area has been gradually increasing. As $80 \%$ of the forest area is nationalized and managed by the State Forests Holding, which is primarily focused on the sustainable use of forest resources, the future health of Polish forests looks promising.

Author Contributions: All authors (Z.S., W.G. and A.S.) substantially conceived the idea, contributed in conceptualization, resources, writing original draft, writing review and editing the text; Z.S. supervision.

Funding: This paper was partially supported from the statutory funds of the Forest Research Institute in Sekocin Stary, Poland, the Warmia and Mazury University in Olsztyn, Poland, and of Warsaw University of Life Sciences-SGGW, Poland.

Acknowledgments: The authors would like to thank the anonymous reviewers for their valuable comments and suggestions.

Conflicts of Interest: Authors declare any personal circumstances or interest that may be perceived as inappropriately influencing the representation or interpretation of reported research results.

\section{References}

1. Broda, J. Dzieje Najnowsze Leśnictwa w Polsce 1918-2006. Tom I, II [Recent Forestry History in Poland. Vol. I, II]; Polskie Towarzystwo Leśne: Warszawa, Poland, 2007.

2. Butterwick, R. Between Anti-Enlightenment and enlightened Catholicism: Provincial preachers in late-eighteenth-century Poland-Lithuania. In Peripheries of the Enlightenment; University of Oxford: Oxford, UK, 2008; Volume 1, pp. 201-228.

3. Klocek, A. Państwowa Administracja Oraz Gospodarka Leśna w Wybranych Krajach [State Administration and Forest Management in Selected Countries]; Centrum Informacyjne Lasów Państwowych: Warszawa, Poland, 2006.

4. Kawecki, W. Lasy Żywiecczyzny, Ich Terazniejszosśc i Przyszłość (Zarys Monograficzny) [Żywiec Region Forests, Their Present and Future (Monographic Outline)]; Prace Roln. Leśne 35. Polska Akademia Umiejętności: Kraków, Poland, 1939.

5. Sierota, Z. Gdy las Choruje [When the Forest Is Ill]; Centrum Informacyjne Lasów Państwowych: Warszawa, Poland, 2011.

6. Zoll, T. Podstawowe zagadnienia zagospodarowania lasów górskich w Sudetach [Basic issues of mountain forest management in the Sudetes]. Sylwan 1958, 102, 9-33.

7. Sitková, Z.; Hlásny, T.; Kulla, L.; Grodzki, W.; Šrámek, V. The Beskids-Region of interest. In Spruce Forests Decline in the Beskids; Hlásny, T., Sitková, Z., Eds.; National Forest Centre-Forest Research Institute Zvolen \& Czech University of Life Sciences Prague \& Forestry and Game Management Research Institute Jíloviště-Strnady: Zvolen, Slovakia, 2010; pp. 9-13.

8. Hlásny, T.; Grodzki, W.; Šrámek, V.; Holuša, J.; Kulla, L.; Sitková, Z.; Turčáni, M.; Raczzka, G.; Strzeliński, P.; Wẹiel, A. Spruce forests decline in the Beskids. In Spruce Forests Decline in the Beskids; Hlásny, T., Sitková, Z., Eds.; National Forest Centre-Forest Research Institute Zvolen \& Czech University of Life Sciences Prague \& Forestry and Game Management Research Institute Jíloviště-Strnady: Zvolen, Slovakia, 2010; pp. 15-31.

9. Kant, S.; Alavalapati, J.R.R. Handbook of Forest Resource Economics; Routledge: New York, NY, USA, 2014.

10. Bytnerowicz, A.; Szaro, R.; Karnosky, D.; Manning, W.; McManus, M.; Musselman, R.; Muzika, R.-M. Importance of international research cooperative programs for better understanding of air pollution effects on forest ecosystems in Central Europe. In Effects of Air Pollution on Forest Health and Biodiversity in Forests of the Carpathian Mountains; Szaro, R.C., Oszlányi, J., Godzik, B., Bytnerowicz, A., Eds.; NATO Science Series, Series I: Life and Behavioural Sciences; IOS Press: Amsterdam, The Netherlands, 2002; Volume 345, pp. 13-20.

11. Barzdajn, W.; Ceitel, J.; Modrzyński, J. Świerk w lasach polskich-Historia, stan, perspektywy [Spruce in Polish forests-History, condition, perspectives]. In Drzewostany Świerkowe. Stan, Problemy, Perspektywy Rozwojowe [Spruce Stands. Condition, Problems, Development Perspectives]; Grzywacz, A., Ed.; Polskie Towarzystwo Leśne: Warszawa, Poland, 2003; pp. 5-22. 
12. Faber, A.; Sabor, J.; Grzebelus, D. Zróżnicowanie genetyczne wybranych drzewostanów świerka pospolitego (Picea abies L. Karst.) na przykładzie rasy istebniańskiej przy wykorzystaniu markerów RAPD [Genetic diversity of Norway spruce (Picea abies L. Karst.) of the Polish provenance from Istebna based on the RAPD analysis]. Zesz. Probl. Post. Nauk Roln. 2007, 517, 277-283.

13. Sturtevant, B.R.; Fall, A.; Kneeshaw, D.D.; Simon, N.P.P.; Papaik, M.J.; Berninger, K.; Doyon, F.; Morgan, D.G.; Messier, C. A toolkit modeling approach for sustainable forest management planning: Achieving balance between science and local needs. Ecol. Soc. 2007, 12, 7. [CrossRef]

14. Rykowski, K. O Leśnictwie Trwałym i Zrównoważonym. W Poszukiwaniu Definicji i Miar [On Permanent and Sustainable Forestry. In Search of Definitions and Measures]; Centrum Informacyjne Lasów Państwowych: Warszawa, Poland, 2006.

15. Borkowski, J. Ministerialny Proces Ochrony Lasów w Europie [Ministerial Process of Forest Protection in Europe]; Biblioteczka Leśniczego 242. Wyd. Świat: Warszawa, Poland, 2011.

16. Smyk, G. Zasady wprowadzania i zakres obowiązywania rosyjskich źródeł prawa w Królestwie Polskim po powstaniu styczniowym [Principles of introduction and scope of operation of Russian sources of law in the Kingdom of Poland after the January Uprising]. Studia z Dziejów Państwa i Prawa Polskiego 2011, 14, 213-239.

17. Beker, C.; Andrzejewski, T. Model wzrostu niepielęgnowanych drzewostanów sosnowych. I. Lokalny model referencyjny Pinus Zielonka [Growth model of unthinned Scots pine stands I. Local reference model Pinus Zielonka]. Acta Sci. Pol. Silv. Colendar. Rat. Ind. Lignar. 2013, 12, 5-13.

18. Klemantowicz, D. Lasy powiatu sieradzkiego w połowie XIX w. [Forests in Sieradz district in the mid-19th century]. Biul. Szadk. 2008, 8, 151-160.

19. Capecki, Z. Charakterystyka zdrowotności i zagrożenia lasów karpackich w Polsce [Characteristics of health and threats in the Carpathian forests in Poland]. Pr. Inst. Bad. Leśn. Ser. A 1983, 617, 27-54.

20. Capecki, Z. Stan sanitarny lasów górskich a gradacje szkodników wtórnych [The sanitary state of mountain forests and outbreaks of secondary pests]. Sylwan 1993, 137, 61-68.

21. Poławski, Z.F. Zmiany użytkowania ziemi w Polsce w ostatnich dwóch stuleciach [Land use changes in Poland during last two centuries]. Teledetekcja Środowiska 2009, 42, 69-82.

22. Capecki, Z. Zagrożenie lasów sudeckich przez szkodniki na tle szkód spowodowanych przez huragany i okiść [Threats to Sudety forests by pests on the background of damage caused by hurricanes and snow tufts]. Sylwan 1969, 113, 57-64.

23. Michalski, J. Gradacje kornikowe w ostatnim 50-leciu w drzewostanach świerkowych Polski [Bark beetle outbreaks in the last 50 years in spruce stands of Poland]. In Biologia Świerka Pospolitego [Biology of Norway Spruce]; Boratyński, A., Bugała, W., Eds.; Bogucki Wydawnictwo Naukowe: Poznań, Poland, 1998; pp. 468-508.

24. Smykała, J. Historia, rozmiar i rozmieszczenie zalesień gruntów porolnych w Polsce w latach 1945-1987 [History, area and distribution of afforestation of post-agricultural lands in Poland in the years 1945-1987]. Sylwan 1990, 134, 1-7.

25. Dekret Polskiego Komitetu Wyzwolenia Narodowego z Dnia 6 Września 1944 r. o Przeprowadzeniu Reformy Rolnej [Decree Polish Committee of National Liberation about Implementing the Land Reform]; PKWN: Lublin, Poland, 1944.

26. Sierota, Z. Heterobasidion annosum on Poland's former agricultural lands-Scope of menace and prevention. Sci. Res. Essays 2013, 8, 2298-2305. [CrossRef]

27. Woreta, D.; Sukovata, L. Survival and growth of the Melolontha spp. grubs on the roots of the main forest tree species. Leś. Pr. Bad./For. Res. Pap. 2014, 75, 375-383. [CrossRef]

28. Sierota, Z. An analysis of the root rot spread in a Scots pine stand growing in post-agricultural land. Fol. For. Pol. Ser. A For. 1997, 39, 27-37.

29. Małecka, M.; Hilszczańska, D. Influence of resting and pine sawdust application on chemical changes in post-agricultural soil and the ectomycorrhizal community of growing Scots pine saplings. Leś. Pr. Bad./For. Res. Pap. 2015, 76, 265-272. [CrossRef]

30. Kolk, A. Impact of bark beetles on forest management in Poland in 1981-1990. J. Appl. Entomol. 1992, 114, 425-430. [CrossRef]

31. Lipa, J.J.; Kolk, A. The recent situation of the gypsy moth (Lymantria dispar) and other Lymantriids in Poland. Bull. OEPP/EPPO Bull. 1995, 25, 623-629. [CrossRef]

32. Capecki, Z. Specyfika zdrowotności lasów wschodniej części Karpat [Specific of forest health in the eastern part of the Carpathians]. Sylwan 1999, 143, 81-88. 
33. Sierota, Z. Choroby infekcyjne-Ocena występowania i wpływ na gospodarkę leśna [Infectious diseases-Occurrence and impact on forest management]. Sylwan 1998, 142, 21-37.

34. Sierota, Z.; Małecka, M. Ocena zmian w drzewostanie sosnowym na gruncie porolnym po 30 latach od wykonania pierwszych cięć pielęgnacyjnych bez zabiegu ochronnego przeciw hubie korzeni [Assessment of changes in a pine stand established on post-agricultural land after 30 years from first improvement cutting without application of protective measures against root rot]. Sylwan 2003, 147, 19-26.

35. Skrzecz, I.; Perlińska, A. Current problems and tasks of forest protection in Poland. Fol. For. Pol. Ser. A For. 2018, 60, 161-172. [CrossRef]

36. Geszprych, M. Specyfika nadzoru i sfera wartości w prawie leśnym [Specific character and the sphere of values in forestry law]. Studia Lubuskie 2009, 5, 159-181.

37. Häusler, A.; Scherer-Lorenzen, M. Sustainable Forest Management in Germany: The Ecosystem Approach of the Biodiversity Convention Reconsidered; Bundesamt für Naturschutz-Skripten 51: Bonn, Germany, 2001.

38. Płotkowski, L. Gospodarka leśna w badaniach ekonomiki leśnictwa [Forest management as a subject of forestry economics research]. Roczniki Nauk Rolniczych Seria G 2010, 97, 110-120.

39. Brzeziecki, B. Podejście ekosystemowe i półnaturalna hodowla lasu (w kontekście zasady wielofunkcyjności [Ecosystem approach and close-to-nature silviculture (in context of forest multifunctionality principle)]. Studia i Materiały CEPL 2008, 3, 41-54.

40. Brang, P.; Spathelf, P.; Larsen Bo, J.; Bauhus, J.; Boncčìna, A.; Chauvin, C.; Drössler, L.; García-Güemes, C.; Heiri, C.; Kerr, G.; et al. Suitability of close-to-nature silviculture for adapting temperate European forests to climate change. Forestry 2014, 87, 492-503. [CrossRef]

41. Sierota, Z. (Ed.) Zmiany w Środowisku Drzewostanów Sosnowych na Gruntach Porolnych w Warunkach Przebudowy Częściowej oraz Obecności Grzyba Phlebiopsis gigantea [Changes in Scots Pine Stands Environment on Former Farmlands in Conditions of a Partial Reconstruction and Presence of Phlebiopsis gigantea]; IBL: Sękocin Stary, Poland, 2011.

42. Raport o Stanie Lasów w Polsce [The State Forests in Poland]; Directorate-General of the State Forests: Warszawa, Poland, 2016.

43. Brázdil, R. Meteorological extremes and their impacts on forests in the Czech Republic. In The Impacts of Climate Variability on Forests; Lecture Notes in Earth Sciences 74; Beniston, M., Innes, J.L., Eds.; Springer: Berlin/Heidelberg, Germany, 1998.

44. Heinsdorf, D. The role of nitrogen in declining scots pine forests (Pinus sylvestris) in the lowland of East Germany. Water Air Soil Pollut. 1993, 69, 21-35. [CrossRef]

45. Badea, O.; Tanase, M.; Georgeta, J.; Anisoara, L.; Peiov, A.; Uhlirova, H.; Pajtik, J.; Wawrzoniak, J.; Shparyk, Y. Forest health status in the Carpathian Mountains over the period 1997-2001. Environ. Pollut. 2004, 130, 93-98. [CrossRef]

46. Barzdajn, W. Adaptacja różnych pochodzeń jodły pospolitej (Abies alba Mill.) do warunków Sudetów [Adaptation of different Silver fir (Abies alba Mill.) provenances to the conditions of the Sudetes]. Leśn. Pr. Bad./For. Res. Pap. 2009, 70, 49-58.

47. Percy, K.E. Is air pollution an important factor in forest health. In Effects of Air Pollution on Forest Health and Biodiversity in Forests of the Carpathian Mountains; Szaro, R.C., Oszlányi, J., Godzik, B., Bytnerowicz, A., Eds.; NATO Science Series, Series I: Life and Behavioural Sciences; IOS Press: Amsterdam, The Netherlands, 2002; Volume 345, pp. 23-42.

48. Paschalis, P.; Zajaczkowski, S. (Eds.) Protection of Forest Ecosystems. Selected Problems of Forestry in Sudety Mountains; Grant GEF 05/21685 POL; Forest Biodiversity Protection Project: Warszawa, Poland, 1996.

49. Baltensweiler, W. "Waldsterben": Forest pests and air pollution. Zeitschrift für Angewandte Entomologie 1985, 99, 77-85. [CrossRef]

50. Schutt, P.; Cowling, E.B. Waldsterben, a general decline of forests in central Europe: Symptoms, development and possible causes. Plant Dis. 1985, 69, 548-558.

51. Schultze, E.D. Air pollution and forest decline in a spruce (Picea abies) forest. Science 1989, 244, 776-783. [CrossRef] [PubMed]

52. Kandler, O.; Innes, J.L. Air pollution and forest decline in Central Europe. Environ. Poll. 1995, 90, 171-180. [CrossRef] 
53. Głowacka, B. The control of the nun moth (Lymantria monacha L.) in Poland: A comparison of two strategies. In Population Dynamics, Impacts and Integrated Management of Forest Defoliating Insects; McManus, M.L., Liebhold, A.M., Eds.; USDA Forest Service, General Technical Report NE-247; Northeastern Research Station: Hamden, CT, USA, 1998; pp. 108-115.

54. Schönherr, J. Nun moth outbreak in Poland 1978-1984. Zeitschrift für Angewandte Entomologie 1985, 99, 73-76. [CrossRef]

55. Śliwa, E. Przebieg masowego pojawu brudnicy mniszki (Lymantria monacha L.) i jej zwalczanie w Polsce w latach 1978-1985 oraz regeneracja aparatu asymilacyjnego w uszkodzonych drzewostanach [Course of the mass appearance of the nun moth (L. monacha L). and its control in Poland in the years 1978-1985 and the regeneration of the assimilation apparatus in damaged stands]. Prace Inst. Bad. Lesn. 1989, 710, 1-120.

56. Grodzki, W.; Michalski, J. Historia gradacji kornika drukarza [The history of bark beetle outbreaks]. In Kornik Drukarz Ips typographus (L.) i Jego Rola w Ekosystemach Leśnych [The Spruce Bark Beetle of Ips typographus (L.) and Its Role in Forest Ecosystems]; Grodzki, W., Ed.; Centrum Informacyjne Lasów Państwowych: Warszawa, Poland, 2013; pp. 109-125.

57. Michalski, J.; Starzyk, J.R.; Kolk, A.; Grodzki, W. Zagrożenie świerka przez kornika drukarza-Ips typographus (L.) w drzewostanach Leśnego Kompleksu Promocyjnego "Puszcza Białowieska" w latach 2000-2002 [Threat of Norway spruce caused by the bark beetle Ips typographus (L.) in the stands of the Forest Promotion Complex "Puszcza Białowieska" in 2000-2002]. Leś. Pr. Bad./For. Res. Pap. 2004, 3, 5-30.

58. Brzeziecki, B.; Hilszczański, J.; Kowalski, T.; Łakomy, P.; Małek, S.; Miścicki, S.; Modrzyński, J.; Sowa, J.; Starzyk, J.R. Problem masowego zamierania drzewostanów świerkowych w Leśnym Kompleksie Promocyjnym "Puszcza Białowieska" [Problem of a massive dying-off of Norway spruce stands in the ‘Białowieża Forest' Forest Promotional Complex]. Sylwan 2018, 162, 373-386.

59. Hilszczański, J.; Sierpiński, A. Agrilus spp. the main factor of oak decline in Poland. In Proceedings of the IUFRO Working Party 7.03.10 Workshop, Gmunden, Austria, 11-14 September 2006; pp. 121-125.

60. Moraal, L.G.; Hilszczański, J. The buprestid beetle, Agrilus biguttatus (F.) (Col., Buprestidae), a recent factor in oak decline in Europe. J. Pest Sci. 2000, 5, 134-138.

61. Żółciak, A.; Lech, P.; Małecka, M.; Sierota, Z. Opieńkowa zgnilizna korzeni a stan zdrowotny drzewostanów świerkowych w Beskidach [Armillaria root and the health conditon of Norway spruce stands in the Beskids]. Polska Akademia Umiejętności. Prace Komisji Nauk Rolniczych Leśnych i Weterynaryjnych 2009, 11, 61-71.

62. Grodzki, W. Zagrożenie górskich drzewostanów świerkowych w zachodniej cześci Beskidów ze strony szkodników owadzich [Threats to mountain spruce stands of the insect pests in the western part of Beskidy mountains]. Leś. Pr. Bad./For. Res. Pap. 2004, 2, 35-47.

63. Grodzki, W. The decline of Norway spruce Picea abies (L.) Karst. stands in Beskid Ślaski and Żywiecki: Theoretical concept and reality. Beskydy 2010, 3, 19-26.

64. Grodzki, W.; Starzyk, J.R.; Kosibowicz, M. Variability of selected traits of Ips typographus (L.) (Col.: Scolytinae) populations in Beskid Żywiecki (Western Carpathians, Poland) region affected by bark beetle outbreak. Fol. For. Pol. Ser. A For. 2014, 56, 79-92. [CrossRef]

65. Oszako, T. Przyczyny masowego zamierania drzewostanów dębowych [Causes of oak stand decline]. Sylwan 2007, 151, 62-72.

66. Kowalski, T. Chalara fraxinea sp. nov. associated with dieback of ash (Fraxinus excelsior) in Poland. For. Pathol. 2006, 36, 264-270. [CrossRef]

67. Kowalski, T. Rozprzestrzenienie grzyba Chalara fraxinea w aspekcie procesu chorobowego jesionu w Polsce [Expanse of Chalara fraxinea fungus in terms of ash dieback in Poland]. Sylwan 2009, 153, 668-674.

68. Manion, P.D. Tree Disease Concepts; Prentice-Hall: Englewood Cliffs, NJ, USA, 1991.

69. Innes, J.L. Forest Health: Its Assessment and Status; CAB International: Wallingford, UK, 1993.

70. Sierota, Z. Obserwowane i prawdopodobne zmiany występowania mikroorganizmów chorobotwórczych w związku ze zmianami klimatycznymi oraz ocena ich funkcji ekologicznych w ekosystemach leśnych; potencjalne rozprzestrzenianie się gatunków inwazyjnych [Observed and probable changes in the occurrence of pathogenic microorganisms in relation to climatic changes and assessment of their ecological functions in forest ecosystems; the potential spread of invasive species]. In KLIMAT. Lasy i Drewno a Zmiany Klimatyczne: Zagrożenia i Szanse. Materiaty Pierwszego Panelu Ekspertów w Ramach Prac nad Narodowym Programem Leśnym [CLIMATE. Forests and Wood and Climate Change: Threats and Opportunities. Materials of the First Panel of Experts 
as Part of Work on the National Forest Program]; Rykowski, K., Ed.; Instytut Badawczy Leśnictwa: Sękocin Stary, Poland, 2014; pp. 189-198.

71. Zachara, T. Problem szkód w lasach powodowanych przez śnieg i wiatr oraz sposoby przeciwdziałania im [Damage to forests caused by snow and wind and the ways of counteracting it]. Sylwan 2006, 150, 56-64.

72. Nikolov, C.; Konôpka, B.; Kajba, M.; Galko, J.; Kunca, A.; Janský, L. Post-disaster Forest Management and Bark Beetle Outbreak in Tatra National Park, Slovakia. Mount. Res. Develop. 2014, 34, 326-335. [CrossRef]

73. Pietruńko, G. Analiza zmian przestrzennych w nadleśnictwach Sudetów Zachodnich w oparciu o wyniki przeprowadzonych prac urzadzeniowych [Analysis of spatial changes in the forest districts of the Western Sudetes based on the results of the forest inventory]. Postępy Techniki w Leśnictwie 2004, 89, 22-28.

74. Grodzki, W.; Guzik, M. Wiatro- i śniegołomy oraz gradacje kornika drukarza w Tatrzańskim Parku Narodowym na przestrzeni ostatnich 100 lat. Próba charakterystyki przestrzennej [Wind- and snowfall, and the spruce bark beetle outbreaks in the Tatra National Park over the last 100 years. Attempt to spatial characteristics]. In Dtugookresowe Zmiany w Przyrodzie i Użytkowaniu TPN [Long-Term Changes in Nature and Use of Tatra NP]; Guzik, M., Ed.; Wyd. Tatrzański Park Narodowy: Zakopane, Poland, 2009; pp. 33-46.

75. Capecki, Z. Rejony zdrowotności lasów zachodniej części Karpat [Forest health regions in western Carpathians]. Pr. Inst. Bad. Leśn. Ser. A 1994, 781, 61-125.

76. Małek, S.; Martinson, L.; Sverdrup, H. Modelling future soil chemistry at a highly polluted forest site at Istebna in Southern Poland using the "SAFE" model. Environ. Poll. 2005, 137, 568-573. [CrossRef]

77. Sabor, J. Możliwości zachowania i metody selekcji drzewostanów świerkowych rasy istebniańskiej [Possibilities of preservation and methods of selection of the Istebna breed spruce stands]. Sylwan 1996, 140, 61-81.

78. Kundzewicz, Z.W.; Kowalczak, P. Zmiany Klimatu i Ich Skutki [Climate Changes and Their Impact]; Wydawnictwo Kurpisz SA: Poznań, Poland, 2008.

79. Lindner, M.; Maroschek, M.; Netherer, S.; Kremer, A.; Barbati, A.; Garcia-Gonzalo, J.; Seidl, R.; Delzon, S.; Corona, P.; Kolström, M.; et al. Climate change impacts, adaptive capacity, and vulnerability of European forest ecosystems. For. Ecol. Manag. 2010, 259, 698-709. [CrossRef]

80. Liszewska, M. Klimat w Polsce w XXI wieku-Prawdopodobne kierunki zmian; perspektywa klimatów lokalnych [Climate in Poland in the 21st century-Likely directions of change; the prospect of local climates]. In KLIMAT. Lasy i Drewno a Zmiany Klimatyczne: Zagrożenia i Szanse. Materiały Pierwszego Panelu Ekspertów w Ramach Prac nad Narodowym Programem Leśnym [CLIMATE. Forests and Wood and Climate Change: Threats and Opportunities. Materials of the First Panel of Experts as Part of Work on the National Forest Program]; Rykowski, K., Ed.; Instytut Badawczy Leśnictwa: Sękocin Stary, Poland, 2014; pp. 35-44.

81. Sadowski, M. Przewidywane zmiany klimatu i ich przyrodnicze, społeczne i polityczne konsekwencje [Predicted changes of the climate and their environmental, social, and political consequences]. Sylwan 1996, 140, 83-103.

82. Ryszkowski, L.; Kędziora, A.; Bałazy, S. Przewidywane zmiany globalne klimatu a lasy i zadrzewienia krajobrazu rolniczego [The predicted effect of global changes on midfield forests and shelterbelts in agricultural landscape]. Sylwan 1995, 139, 19-32.

83. Zielony, R. Uwarunkowania siedliskowe gospodarki leśnej u progu XXI wieku-Zarys problem [Site conditions of forest management at the turn of the XX and XXI centuries-Outline of the problem]. In Zgodność Fitocenozy z Biotopem w Ekosystemach Leśnych [Compatibility between Phytocoenosis and Biotope in Forest Ecosystems]; Zielony, R., Ed.; Fundacja Rozwój SGGW: Warszawa, Poland, 2001; pp. 6-8.

84. Rabasa, S.G.; Granda, E.; Benavides, R.; Kunstler, G.; Espelta, J.M.; Ogaya, R.; Peñuelas, J.; Scherer-Lorenzen, M.; Gil, W.; Grodzki, W.; et al. Disparity in elevational shifts of European trees in response to recent climate warming. Glob. Chang. Biol. 2013, 19, 2490-2499. [CrossRef]

85. Tokarska-Guzik, B.; Dajdok, Z.; Zając, M.; Zając, A.; Urbisz, A.; Danielewicz, W.; Hołdyński, C. Rośliny Obcego Pochodzenia w Polsce ze Szczególnym Uwzględnieniem Gatunków Inwazyjnych [Alien Plants in Poland with Particular Reference to Invasive Species]; Generalna Dyrekcja Ochrony Środowiska: Warszawa, Poland, 2012.

86. Szwagrzyk, J. Prawdopodobne zmiany zasięgów występowania gatunków drzewiastych-Konsekwencje dla hodowli lasu [Probable changes in the ranges of tree species occurrence-Consequences for forest breeding]. In KLIMAT. Lasy i Drewno a Zmiany Klimatyczne: Zagrożenia i Szanse. Materiały Pierwszego Panelu Ekspertów w Ramach Prac nad Narodowym Programem Leśnym [CLIMATE. Forests and Wood and Climate Change: 
Threats and Opportunities. Materials of the First Panel of Experts as Part of Work on the National Forest Program]; Rykowski, K., Ed.; Instytut Badawczy Leśnictwa: Sękocin Stary, Poland, 2014; pp. 45-54.

87. Jaworski, T.; Hilszczański, J. The effect of temperature and humidity changes on insects development and their impact on forest ecosystems in the context of expected climate change. Leś. Pr. Bad./ For. Res. Pap. 2013, 74, 345-355. [CrossRef]

88. Hilszczański, J. Dynamika populacji owadów oraz ocena ich funkcji ekologicznych w ekosystemach leśnych w związku ze zmianami klimatycznymi [The dynamics of the insect populations and the assessment of their ecological functions in forest ecosystems in relation to climate change]. In KLIMAT. Lasy i Drewno a Zmiany Klimatyczne: Zagrożenia i Szanse. Materiały Pierwszego Panelu Ekspertów w Ramach Prac nad Narodowym Programem Leśnym [CLIMATE. Forests and Wood and Climate Change: Threats and Opportunities. Materials of the First Panel of Experts as Part of Work on the National Forest Program]; Rykowski, K., Ed.; Instytut Badawczy Leśnictwa: Sękocin Stary, Poland, 2014; pp. 174-188.

89. Mokrzycki, T.; Plewa, R. Kornik Ostrozębny_Ips acuminatus (Gyllenhal, 1827) (Coleoptera, Curculionidae, Scolytinae)—Występowanie, Biologia i Znaczenie Gospodarcze w Lasach Polski [Ips acuminatus (Gyllenhal, 1827) (Coleoptera, Curculionidae, Scolytinae)_Occurrence, Biology and Economic Importance in the Forests of Poland]; Biblioteczka Leśniczego 382. Wyd. Świat: Warszawa, Poland, 2017.

90. Nowakowska, J.A. Tempo rozprzestrzeniania się nowych inwazyjnych szkodników i patogenów drzew w ekosystemach leśnych w Europie na podstawie modelowania komputerowego w latach 2014-2100 [The rate of spread of new invasive pests and tree pathogens in forest ecosystems in Europe based on computer modeling in 2014-2100]. Leś. Pr. Bad./For. Res. Pap. 2014, 75, 325-326.

91. Kosibowicz, M. Owady inwazyjne w lasach Polski [Invasive insects in the forests of Poland]. Wszechświat 2009, 110, 51-54.

92. Kowalski, T. Zamieranie Pędów Sosny [Pine Shoots Dieback]; Biblioteczka leśniczego 80; Wydawnictwo Świat: Warszawa, Poland, 1997.

93. Orlikowski, L.; Oszako, T. (Eds.) Fytoftorozy w Szkółkach i Drzewostanach Leśnych [Phytophthorosis in Nurseries and Forest Stands]; Centrum Informacyjne Lasów Państwowych: Warszawa, Poland, 2009.

94. Mułenko, W.; Piątek, M.; Wołczańska, A.; Kozłowska, M.; Ruszkiewicz-Michalska, M. Plant parasitic fungi introduced to Poland in modern times. Alien and invasive species. In Biological Invasions in Poland; Mirek, Z., Ed.; W. Szafer Institute of Botany, Polish Academy of Sciences: Kraków, Poland, 2010; Volume 1, pp. 49-71.

95. Szczepkowski, A. Perenniporia fraxinea (Fungi, Polyporales), a new species for Poland. Pol. Bot. J. 2004, 49, 73-77.

96. Szczepkowski, A. Macromycetes in the Dendrological Park of the Warsaw Agricultural University. Acta Mycol. 2007, 42, 179-186. [CrossRef]

97. Kreisel, H. Global warming and mycoflora in the Baltic Region. Acta Mycol. 2006, 41, 79-94. [CrossRef]

98. Wojewoda, W.; Karasiński, D. Invasive macrofungi (Ascomycota and Basidiomycota) in Poland. In Biological Invasions in Poland; Mirek, Z., Ed.; W. Szafer Institute of Botany, Polish Academy of Sciences: Kraków, Poland, 2010; Volume 1, pp. 7-21.

99. Szczepkowski, A.; Obidziński, A. Obce gatunki sromotnikowatych Phallaceae w lasach Polski [Alien species of stinkhorns Phallaceae in forests of Poland]. Studia i Materiaty CEPL w Rogowie 2012, 33, 279-295.

100. Wrzosek, M.; Motiejūnaite, J.; Kasparavičius, J.; Wilk, M.; Mukins, E.; Schreiner, J.; Vishnevskiy, M.; Gorczak, M.; Okrasińska, A.; Istel, Ł.; et al. The progressive spread of Aureoboletus projectellus (Fungi, Basidiomycota) in Europe. Fungal Ecol. 2017, 27, 134-136. [CrossRef]

101. Breshears, D.D.; Myers, O.B.; Meyer, C.W.; Barnes, F.J.; Zou, C.B.; Allen, C.D.; McDowell, N.G.; Pockman, W.T. Tree die-off in response to global-change type drought: Mortality insights from a decade of plant water potential measurements. Front. Ecol. Environ. 2009, 7, 185-189. [CrossRef]

102. Białooki, P. Anoplophora glabripennis [Motschulsky] [Coleoptera: Cerambycidae]—Pierwsze stwierdzenie w Polsce [Anoplophora glabripennis [Motschulsky] [Coleoptera: Cerambycidae]—First confirmation in Poland]. Ochrona Roślin 2003, 47, 34-35.

103. Mokrzycki, T.; Grodzki, W. Drzewotocz japoński Xylosandrus germanus (Bldf.) (Coleoptera: Curculionidae, Scolytinae) w Polsce [Xylosandrus germanus (Bldf.) (Coleoptera: Curculionidae, Scolytinae) in Poland]. Sylwan 2014, 158, 590-594. 
104. Mazur, A.; Witkowski, R.; Góral, J.; Rogowski, G. Occurrence of Gnathotrichus materiarius (Fitch, 1858) (Coleoptera, Curculionidae, Scolytinae) in South-Western Poland. Fol. For. Pol. Ser. A For. 2018, 60, 154-160. [CrossRef]

105. Kubiak, K.; Żółciak, A.; Damszel, M.; Lech, P.; Sierota, Z. Armillaria Pathogenesis under Climate Changes. Forests 2017, 8, 100. [CrossRef]

106. Szczepkowski, A. Objawy zamierania buków oraz związek między stopniem uszkodzenia drzew a wybranymi cechami taksacyjnymi drzewostanów [Symptoms of beech decline and the relationship between tree damage level and selected inventory traits of tree stand]. Sylwan 2001, 145, 85-99.

107. Szczepkowski, A.; Szyndel, M.S. Attempts to detect and to determine the significance of plant viruses in beech tree decline in Poland. Phytopathol. Pol. 2001, 21, 45-53.

108. Szczepkowski, A.; Tarasiuk, S. Stan zdrowotny zagrożonych zamieraniem drzewostanów bukowych w Polsce [Health status of threatened European beech (Fagus sylvatica L.) stands in Poland]. Acta Sci. Pol. Silv. Colendar. Rat. Ind. Lignar. 2005, 4, 71-85.

109. Tarasiuk, S.; Szczepkowski, A. The health status of endangered oak stands in Poland. Acta Sci. Pol. Silv. Colendar. Rat. Ind. Lignar. 2006, 5, 91-106.

110. Jung, T. Beech decline in Central Europe driven by the interaction between Phytophthora infections and climatic extremes. For. Path. 2008, 39, 77-94.

111. Grodzki, W.; Oszako, T. (Eds.) Current Problems of Forest Protection in Spruce Stands under Conversion; Forest Research Institute: Warsaw, Poland, 2008.

112. Agerer, R. Exploration types of ectomycorrhizae. Mycorrhiza 2001, 11, 107-114. [CrossRef]

113. Agerer, R. Fungal relationships and structural identity of their ectomycorrhizae. Mycol. Prog. 2006, 5, 67-107. [CrossRef]

114. Yafetto, L.; Davis, D.J.; Money, N.P. Biomechanics of invasive growth by Armillaria rhizomorphs. Fungal Genet. Biol. 2009, 46, 688-694. [CrossRef] [PubMed]

115. Pratt, J.E.; Niemi, M.; Sierota, Z.H. Comparison of three products based on Phlebiopsis gigantea for the control of Heterobasidion annosum in Europe. Biocontrol Sci. Technol. 2000, 10, 467-477. [CrossRef]

116. Żółciak, A. Opieńki [Honey Fungi]; Centrum Informacyjne Lasów Państwowych: Warszawa, Poland, 2005.

117. Sierota, Z.; Nowakowska, J.; Sikora, K.; Wrzosek, M.; Żółciak, A.; Małecka, M. What is important in selecting Phlebiopsis gigantea strain for commercial use? J. Agric. Sci. Technol. B 2015, 5, 55-64. [CrossRef]

118. Tyburski, Ł.; Zaniewski, P.T.; Bolibok, L.; Piątkowski, M.; Szczepkowski, A. Scots pine Pinus sylvestris mortality after surface fire in oligotrophic pine forest Peucedano-Pinetum in Kampinos National Park. Fol. For. Pol. Ser. A For. 2019, in press.

119. Gierczyk, B.; Szczepkowski, A.; Kujawa, A.; Ślusarczyk, T. Contribution to the knowledge of mycobiota of the Kampinos National Park (Poland). Part 2. Acta Mycol. 2019, in press. 